[Agr. Biol. Chem., Vol. 35, No. 9, p. 1407 1414, 1971]

\title{
Production of Alkaline Enzymes by Alkalophilic Microorganisms
}

Part I. Alkaline Protease Produced by Bacillus No. 221

\author{
By Koki HoRIKoshI
}

The Institute of Physical and Chemical Research, Wako-shi, Saitama-ken, 351

Received March 10, 1971

\begin{abstract}
A crystalline alkaline protease was prepared from Bacillus No. 221 isolated from soil. The characteristic point of this microorganism is especially good growth in alkaline media. The enzyme was most active at $\mathrm{pH} \quad 11.5 \sim 12$ towards casein and was stable at $\mathrm{pH}$ values from 4 to 11 on $10 \mathrm{~min}$ incubation at $60^{\circ} \mathrm{C}$. Calcium ion was effective to stabilize the enzyme especially at higher temperatures. The enzyme was completely inactivated by DFP and urea, but not affected by sulfhydryl reagent, EDTA, SLS, and DBS. The specific activity of the enzyme towards casein was about $18,000 \mathrm{unit} / \mathrm{mg}$, and the isoelectric point was higher than $\mathrm{pH}$ 9.4. The molecular weight and sedimentation constant was approximately 30,000 and $3.5 S$ respectively, and N-terminal of the enzyme was identified to be alanine. The results indicate that the No. 221 alkaline protease is different from those of alkaline proteases of Bacillus subtilis.
\end{abstract}

It has been reported that a certain species of bacteria can grow in high alkaline media containing high concentration of sodium carbonate or sodium bicarbonate." Some of these bacteria produce a large amount of alkaline protease, and neither neutral nor acid protease can be detected in the culture broth.

Bacillus No. 221 isolated from soil accumulates a large amount of alkaline protease which is entirely different from Bacillus subtilis alkaline proteases. ${ }^{2-4)}$ The newly isolated enzyme of Bacillus No. 221 is most active at $\mathrm{pH} 11 \sim$ 12. This paper deals with isolation of the strain Bacillus No. 221 and some properties of the crystalline alkaline protease.

1) K. Horikoshi, Proc. Agr. Chem. Soc. Japan, p. 201 (1971).

2) A. V. Guntelburg and M. Ottesen, Compt. Rend. Trav. Lab. Carlsberg, 29, 36 (1954).

3) B. Hagihara, "The Enzyme," Vol. 4, ed. by Boyer, Lardy, and Myrback, Academic Press Inc., New York, 1958, p. 193.

4) D. Tsuru, H. Kira, T. Yamamoto and J. Fukumoto, J. Agr. Biol. Chem., 30, 1261 (1966).

\section{MATERIALS AND METHODS}

Medium. An isolation medium (I-medium) contained: glucose, $10 \mathrm{~g}$; polypeptone, $5 \mathrm{~g}$; Difco yeast extract, $5 \mathrm{~g} ; \mathrm{K}_{2} \mathrm{HPO}_{4}, \mathrm{l}$; $\mathrm{MgSO}_{4} 7 \mathrm{H}_{2} \mathrm{O}, 0.2 \mathrm{~g} ; \mathrm{Na}_{2} \mathrm{CO}_{3}$, $10 \mathrm{~g}$ and 1 liter of distilled water. Sodium carbonate was sterilized separately and added to the medium. The I-medium was solidified by the addition of agar $(1.5 \% \mathrm{w} / \mathrm{v})$, if necessary.

Isolation method of alkalophilic bacteria. A small amount of soil was suspended in sterilized water and spread on I-medium agar plates. The plates were incubated at $37^{\circ} \mathrm{C}$ for 24 to $48 \mathrm{hr}$. Bacillus No. 221 producing large amount of alkaline protease was isolated from about 400 colonies.

Characterization and identification of bacteria. Microbiological properties were investigated according to the methods described in "Aerobic Sporeforming Bacteria" 5 and "Bergey's Manual of Determinative Bacteriology, ", Unless stated otherwise, media used

5) N. R. Smith, R. E. Gordon and F. E. Clark, "Aerobic Sporeforming Bacteria," U.S. Dept. of Agric., 1952 .

6) R. S. Breed, E. G. D. Murray and N. R. Smith, "Bergey's Manual of Determinative Bacteriology," Williams and Wilkins Co., Baltimore, 1957. 
for the identification were supplemented with $1 \%$ $\mathrm{Na}_{2} \mathrm{CO}_{3}$.

Preparation of crude enzyme solution. Bacillus No. 221 was grown aerobically at $37^{\circ} \mathrm{C}$ in $I$-medium. After 3 days of incubation with shaking, cell-free enzyme solutions were prepared by centrifugation at $6,000 \times g$ for $10 \mathrm{~min}$.

Assay of enzyme activity. An enzyme solution ( $1 \mathrm{ml}$ ) suitably diluted was mixed with $5 \mathrm{ml}$ of $0.6 \%$ Hammersten casein solution ( $\mathrm{pH}$ 11.5, made up with $2 \times 10^{-2} \mathrm{M} \mathrm{Na} \mathrm{HPO}_{4}-\mathrm{NaOH}$ buffer) at $30^{\circ} \mathrm{C}$. After $10 \mathrm{~min}$ incubation, $5 \mathrm{ml}$ of trichloroacetic acid (TCA) solution (consisting of $0.11 \mathrm{M}$ TCA, $0.22 \mathrm{M}$ sodium acetate and $0.33 \mathrm{M}$ acetic acid) was added to the reaction mixture. The mixture was further incubated at $30^{\circ} \mathrm{C}$ for $30 \mathrm{~min}$ and then filtered. An absorbance of the filtrate was measured at $275 \mathrm{~m} \mu$. One unit of the protease activity is defined as the amount of the enzyme to produce the digest which is not precipitated by TCA solution and which gives absorbance value equivalent to $1 \mathrm{\mu g}$ of tyrosine per $\min$ at $30^{\circ} \mathrm{C}$.

Protein concentration. Purified enzyme concentration was determined spectrophotometrically on the basis that $E_{1 \mathrm{~cm}}^{1 \%}$ at $280 \mathrm{~m} \mu$ of the alkaline protease of Bacillus No. 221 (No. 221 protease) was 12.5, which was determined by the weight of the crystallized No. 221 protease. Protein in a crude solution was measured by the method of Lowry et al. ${ }^{7}$

Electrophoresis and ultracentrifugal analysis. Electrophoretic experiments were carried out by using a Hitachi Tiselius Electrophoresis Apparatus HT-B. A Hitachi Analytical Ultracentrifuge UCA-1 was used for ultracentrifugal analysis, and the sedimentation constant was calculated by the method of Schachman. ${ }^{81}$

Amino acid analysis. The crystalline enzyme preparation was dissolved in water and precipitated with acetone $(80 \%)$. The protein was collected by centrifugation, washed three times with acetone and ether, and then dried in vacuo at $100^{\circ} \mathrm{C}$. After acid hydrolysis, the hydrolyzate was analyzed with a Hitachi Amino Acid Analyzer KLA-3B.

7) O. H. Lowry, N. J. Rosebrough, A. L. Farr and R. J. Randall, J. Biol. Chem., 193, 277 (1951).

8) H. K. Schachman, "Method in Enzymology," ed. by C. P. Clowick and N. O. Koplan, Academic Press Inc. New York, Vol. IV, 1957, p. 32.
$N$-Terminal analysis by dinitrophenyl method. The procedure of Frankel-Conrat, Harris, and Levy as applied by Waller ${ }^{9 /}$ was used for the identification of N-terminal. The reaction with 2-fluorodinitrobenzene was performed in $8 \mathrm{M}$ urea at $40^{\circ} \mathrm{C}$ in the presence of $0.1 \mathrm{M}$ sodium bicarbonate. The reaction product was successively washed with $\mathrm{HCl}$, acetone, and ether. The dinitrophenyl (DNP-) protein (about $100 \mathrm{mg}$ ) was hydrolyzed in a 1.7 evacuated sealed tube with constant boiling $\mathrm{HCl}$ at $110^{\circ} \mathrm{C}$ for $12 \mathrm{hr}$. DNP. amino acid was extracted with ether from the hydrolyzate and chromatographed on silica gel thin-layer chromatography plates. Two dimensional chromatography was performed with toluene-pyridine-ethylenchlorohydrin- $0.8 \mathrm{~N} \mathrm{NH}_{4} \mathrm{OH}(100: 30: 60: 60 \mathrm{v} / \mathrm{v})$ system in the first direction and a chloroform-methanolglacial acetic acid $(95: 5: 1 \mathrm{v} / \mathrm{v})$ system in the second direction.

\section{RESULTS}

Characters of Bacillus No. 221

The isolated strain No. 221 was an aerobic, sporeforming, gram positive, motile, and rodshaped bacterium. It is clear that the bacterium should belong to the genous Bacillus. The characteristic point of the microorganism was that the growth was especially good in alkaline media, the optimal $\mathrm{pH}$ for growth being about 10 . Table I summerizes the morophological and cultural characteristics of the strain No. 221.

\section{Purification of alkaline protease}

To 1 liter of the culture fluid $(6,300 \mathrm{u} / \mathrm{ml})$, 5 liters of cold acetone were added, the precipitate was collected by centrifugation, and washed with cold acetone. About $25 \mathrm{~g}$ of brownish powder were obtained. The acetone dried powder was washed three times with $80 \%$ saturated ammonium sulfate, dissolved in water, and dialyzed against $0.01 \mathrm{M}$ phosphate buffer ( $\mathrm{pH} 7.5$ ) for $24 \mathrm{hr}$. The dialyzate $(100 \mathrm{ml})$ was passed through a DEAE-cellulose

9) J. I. Waller and J. I. Harris, Proc. Natl. Acad. Sci. U.S.A., 47, 18 (1961). 
Table I. Morophological, Cultural, and Biochemical Gharacteristics of Strain No. 221

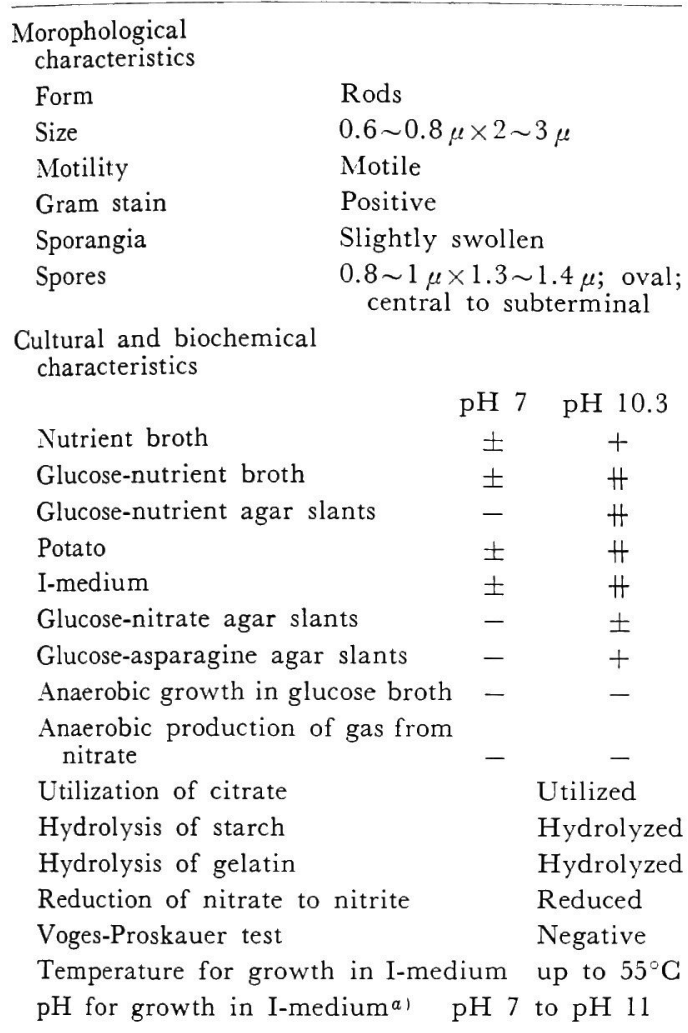

a) $\mathrm{pH}$ in the I-medium was adjusted by the addition of $\mathrm{HCl}$ or $\mathrm{NaOH}$.

- indicates no growth; \pm , poor growth; + normal growth; H, growth abundant. column $(4 \times 30 \mathrm{~cm})$ which had been equilibrated with $0.01 \mathrm{M}$ phosphate buffer $(\mathrm{pH} 7.5)$. The No. 221 protease was not adsorbed with the DEAE-cellulose column, but passed through the column. The effluent (about $150 \mathrm{ml}$ ) was loaded on a CM-cellulose column $(3 \times 30 \mathrm{~cm})$ equilibrated with $0.01 \mathrm{M}$ phosphate buffer ( $\mathrm{pH} 7.5$ ), by which the enzyme was completely adsorbed. The column was washed with $0.01 \mathrm{M}$ phosphate buffer ( $\mathrm{pH}$ 7.5) and the enzyme was eluted with $0.01 \mathrm{M}$ phosphate buffer $(\mathrm{pH}$ 7.5) containing $0.15 \mathrm{M} \mathrm{NaCl}$. The enzyme was precipitated with $50 \%$ saturation of ammonium sulfate, and dissolved in $9 \mathrm{ml}$ of $5 \mathrm{mM} \mathrm{CaCl}{ }_{2}$. The enzyme solution was brought to $30 \%$ saturation with ammonium sulfate. The co-

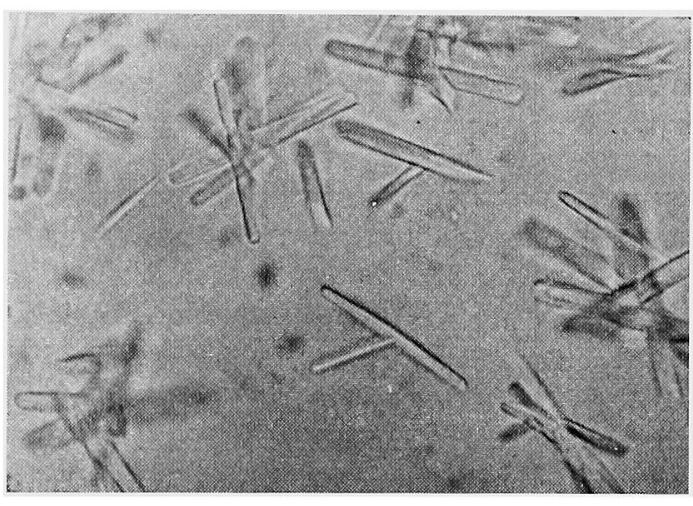

$(\times 1600)$

FIG. 1. Micrograph of Crystalline Alkaline Protease.

Table II. Purification of Alkaline Protease

\begin{tabular}{lccccc}
\hline \multicolumn{1}{c}{ Steps } & $\begin{array}{c}\text { Volume } \\
(\mathrm{ml})\end{array}$ & Unit/ml & $\begin{array}{c}\text { Protein } \\
(\mathrm{mg})\end{array}$ & $\begin{array}{c}\text { Specific activity } \\
\text { (unit/mg protein) }\end{array}$ & $\begin{array}{c}\text { Recovery } \\
(\%)\end{array}$ \\
\hline Culture fluid & 1,000 & 6,300 & $2,000^{a)}$ & 3,150 & 100 \\
Acetone-dried & $21 \mathrm{~g}$ & & & & 95 \\
DEAE-cellulose & 140 & 40,000 & 320 & 17,000 & 87 \\
CM-cellulose & 50 & 80,000 & 220 & 18,000 & 62 \\
Crystals (1st) & & & 165 & 19,000 & 50 \\
Crystals (2nd) & & & 142 & 18,500 & 42 \\
\hline
\end{tabular}

a) The culture fluid was neutralized with $\mathrm{HCl}$ and an equal volume of $10 \%$ perchloric acid was added. The precipitates were dissolved in $0.5 \mathrm{~N} \mathrm{NaOH}$ and protein was determined by the method of Lawry et al. ${ }^{81}$ 
lumnar crystals were observed after a few hours. Figure 1 shows the crystals of No. 221 protease. Table II summarizes the results of the purification of the enzyme.

\section{Effect of $p H$ on activity}

Figure 2 shows the effect of $\mathrm{pH}$ on the protease activity. The $\mathrm{pH}$ was adjusted with the following buffer systems: $0.02 \mathrm{M}$ Tris-HCl (pH $7 \sim 9$ ); $0.02 \mathrm{M}$ Carbonate-Bicarbonate $(\mathrm{pH}$ $9 \sim 10.5) ; 0.02 \mathrm{M}$ Borax-NaOH $(\mathrm{pH} 9 \sim 11) ; 0.02 \mathrm{M}$ $\mathrm{Na}_{2} \mathrm{HPO}_{4}-\mathrm{NaOH}(\mathrm{pH} 10 \sim 11$ ), and $0.02 \mathrm{M} \mathrm{KCl}-$ $\mathrm{NaOH}(\mathrm{pH} 12 \sim 13)$. Other conditions were the same as those of the standard assay method. The enzyme was most active at a $\mathrm{pH}$ range between 11 and 12 toward casein.

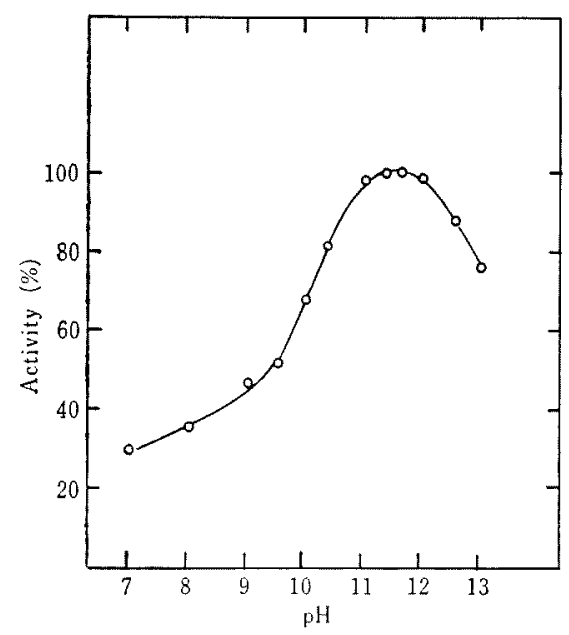

FIG. 2. Effect of $\mathrm{pH}$ on Enzyme Activity.

The following buffer systems were used: $0.02 \mathrm{M}$ Tris-HCl (pH $7 \sim 9$ ); $0.02 \mathrm{M}$ carbonate-bicarbonate $(\mathrm{pH} 9 \sim 10.5) ; 0.02 \mathrm{M}$ Borax-NaOH $(\mathrm{pH} \quad 9 \sim 11)$; $0.02 \mathrm{M} \mathrm{Na}_{2} \mathrm{HPO}_{4}-\mathrm{NaOH}(\mathrm{pH} 10 \sim 11) ; 0.02 \mathrm{M} \mathrm{KCl}-$ $\mathrm{NaOH}(\mathrm{pH} 12 \sim 13)$. Other conditions were the same as those of the standard assay method.

Effect of $p H$ on stability of the enzyme

Stablility of the enzyme was investigated in buffer solutions of various $\mathrm{pH}$ 's containing $3 \mathrm{mM}$ of $\mathrm{Ca}^{2+} \quad$ The reaction mixtures were incubated at $60^{\circ} \mathrm{C}$ for $10 \mathrm{~min}$ and residual

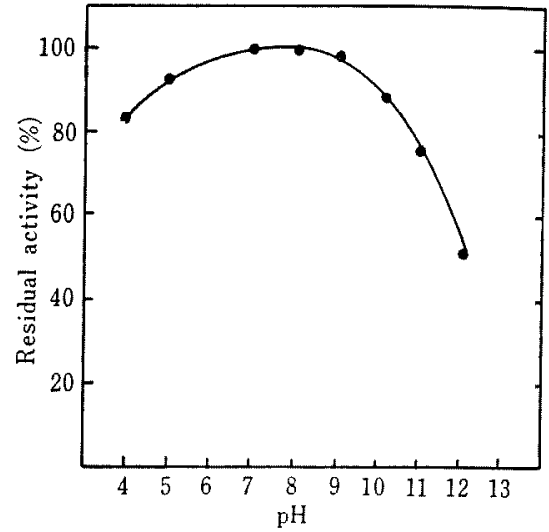

FIG. 3. Effect of $\mathrm{pH}$ on Stability.

Buffer systems used were acetate $(0.02 \mathrm{M}, \mathrm{pH} 4 \sim$ 6); Tris-HCl (0.02 M, pH 7 9 ), and Borax-NaOH$\mathrm{NaCl}(0.02 \mathrm{M}, \mathrm{pH} 9 \sim 12)$. The reaction mixture were incubated at $60^{\circ} \mathrm{C}$ for $10 \mathrm{~min}$ and the remaining activity was measured at $\mathrm{pH} 11.5$.

activity was measured at $\mathrm{pH}$ 11.5. The following buffer systems were used: Acetate (0.02 M, pH 4 6); Tris-HCl (0.02 M, pH 7 9), and Borax- $\mathrm{NaOH}-\mathrm{NaCl}$ (0.02 M, pH 9 12). As shown in Fig. 3, the enzyme was most stable at $\mathrm{pH} 7 \sim 8$.

\section{Temperature optimum for the enzyme action and thermal stability}

The optimum temperature was determined by varying the incubation temperature. The measurement was carried out in the presence or absence of $\left.5 \mathrm{mM} \mathrm{CaCl}\right|_{2}$. In Fig. 4, the activity measured at $30^{\circ} \mathrm{C}$ is expressed as $100 \%$. The activity at $60 \sim 65^{\circ} \mathrm{C}$ in the presence of $\mathrm{Ca}^{2+}$ was about $700 \%$ and that at $60^{\circ} \mathrm{C}$ in the absence of $\mathrm{Ca}^{2+}$ was about $400 \%$.

The enzyme was dissolved in $0.05 \mathrm{M}$ Borax$\mathrm{NaON}(\mathrm{pH} 10.0)$ in the presence or absence of $5 \mathrm{mM} \mathrm{Ca}{ }^{2+}$, incubated at various temperatures for $10 \mathrm{~min}$, and residual activity was measured at $\mathrm{pH}$ 11.5. As shown in Fig. 5, the residual activity was $100 \%$ when heated at $30 \sim 60^{\circ} \mathrm{C}$ in the presence of $\mathrm{Ca}^{2+}$, and $50 \%$ at $65^{\circ} \mathrm{C}$. 


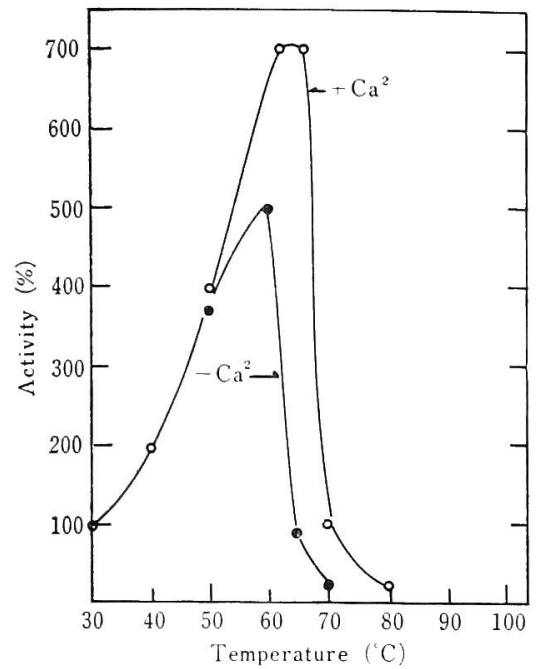

FIG. 4. Optimum Temperature for Enzyme Action.

The reaction was carried out at the temperature indicated for $10 \mathrm{~min}$ at $\mathrm{pH} 11.5$. Open circle, in the presence of $\mathrm{Ca}^{2+}$; closed circle, in the absence of $\mathrm{Ca}^{2+}$.

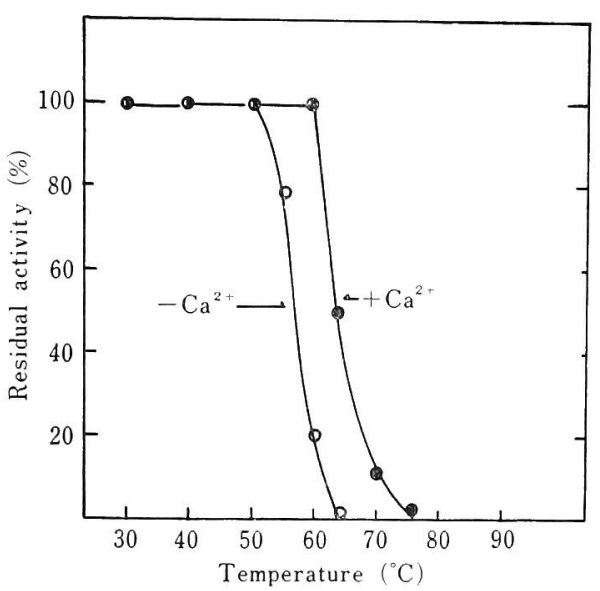

FIG. 5. Effect of Temperature on the Stability of the Enzyme.

The enzyme was dissolved in Borax- $\mathrm{NaOH}$

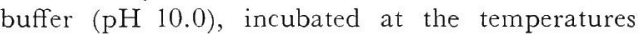
indicated for $10 \mathrm{~min}$, and the residual activities were measured.

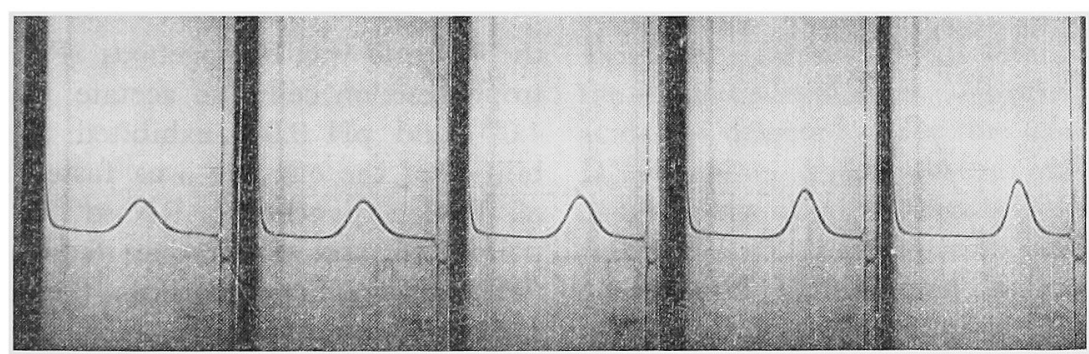

A

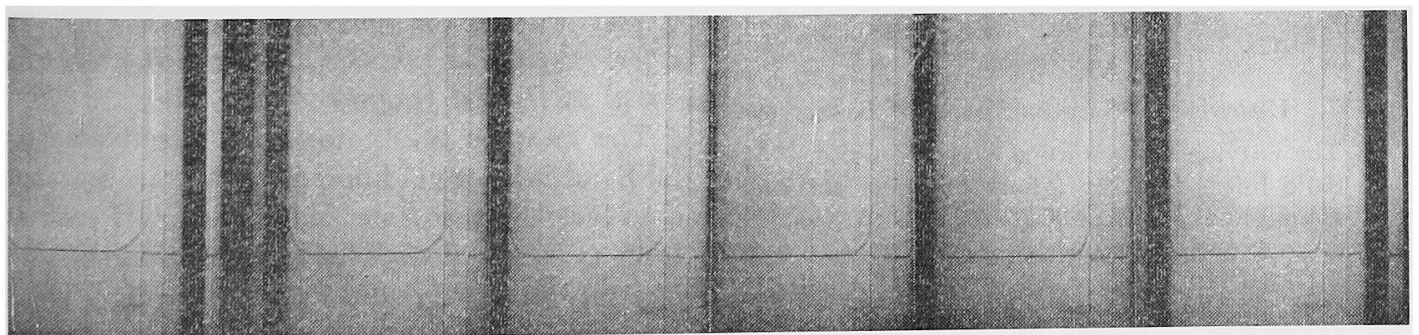

$\mathrm{B}$

FIG. 6. Ultracentrifuge Pattern and Archibald Run of Alkaline Protease.

A: The sedimentation velocity run. The photographs were taken from right to left at $10 \mathrm{~min}$ intervals after reaching the full speed, $55,430 \mathrm{rpm}$. The enzyme concentration used was $0.7 \%$ in 0.04 м Tris- $\mathrm{HCl}$ buffer, $\mathrm{pH} 8.0$, containing $0.005 \mathrm{M} \mathrm{CaCl}_{2}$.

B: Archibald run. The photographs were taken at $10 \mathrm{~min}$ intervals after reaching the full speed, 16,890 rpm. The enzyme concentration used was $0.40^{\prime}$ in $0.04 \mathrm{M}$ Tris-HCl buffer, $\mathrm{pH} 8.0$, containing $0.005 \mathrm{M} \mathrm{CaCl}_{2}$. 
Sedimentation constant and molecular weight

The crystalline enzyme showed only one peak throughout the duration of a run of $120 \mathrm{~min}$ at $55,430 \mathrm{rpm}$. The sedimentation constant of the enzyme at $\mathrm{pH} 7.2$ was about $3.5 \mathrm{~S}$. Molecular weight determined by the method of Archibald $^{8)}$ was about 30,000, (Fig. 6).

\section{Ultraviolet absorption spectra}

Ultraviolet absorption spectra of the enzyme are shown in Fig. 7. Absorbance of $1 \%$ enzyme solution (Tris-HCl buffer $\mathrm{pH} 8.0,0.02 \mathrm{M}$ ) at $280 \mathrm{~m} \mu$ was about 12.5 and the ratio of absorption at $280 \mathrm{~m} \mu$ to $260 \mathrm{~m} \mu$ was about 2.1, which indicated the absence of nucleic acid.

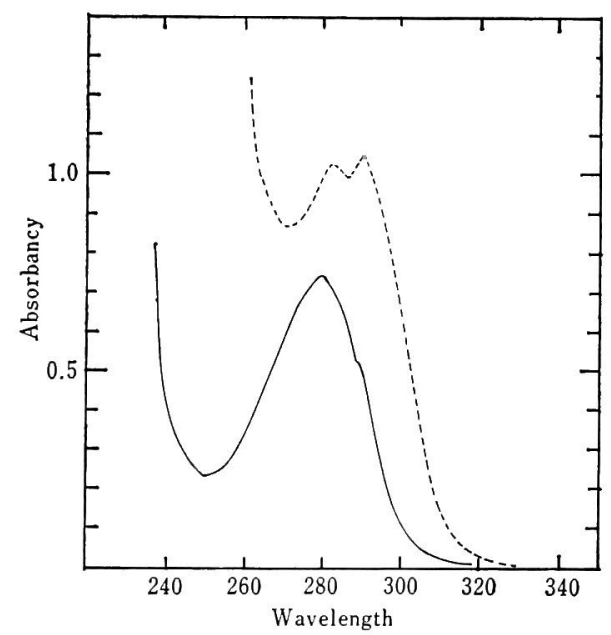

FIG. 7. Ultraviolet Absorption Spectra of the Enzyme.

The enzyme concentration was $590 \mu \mathrm{g} / \mathrm{ml}$.

Solid line: In $0.1 \mathrm{M}$ Tris-HCl buffer $(\mathrm{pH} 7.0)$.

Dotted line: In $0.2 \mathrm{M} \mathrm{KCl-NaOH}$ buffer ( $\mathrm{pH} 12$ ).

\section{Isoelectric point of the enzyme}

Result of the Tiselius electrophoresis at $\mathrm{pH} 9.4^{101}$ showed that the isoelectric point of the enzyme was higher than $\mathrm{pH} 9.4$ and that

10) "Data for Biochemical Research," ed. by R. M. C. Dawson, et al., Oxford at Clarendon Press, 1969 , p. 500 .

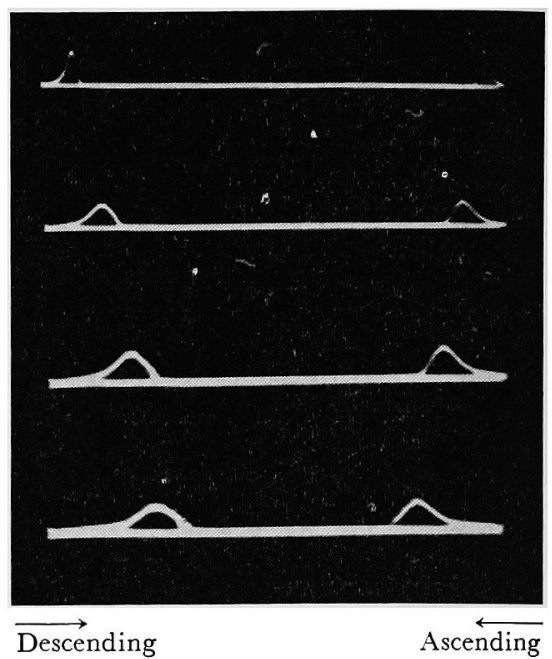

FIG. 8. Electrophoretic Pattern of the Enzyme.

The electrophoresis was carried out at $6 \mathrm{~mA}$ and $15^{\circ} \mathrm{C}$. The enzyme concentration was $0.7 \%$ in glycine-NaOH-NaCl buffer $(\mathrm{pH} 9.4, \mathrm{I}=0.1) .{ }^{101}$

the enzyme was homogenous (Fig. 8). Electrophoresis on cellulose acetate plates at $\mathrm{pH}$ $4.0^{101}$ and $\mathrm{pH} 9.0^{101}$ exhibited that the mobilities of the enzyme was faster than those of Bovine panceratic RNase A (isoelectric point $=9.6$ ) and slower than those of lysozyme (isoelectric point $=11$ ). From these results, the isoelectric point of the enzyme should be about 10 .

Effect of protease inhibitor, surface active reagents, and sulfhydryl reagents

The enzyme was completely inactivated by DFP (diisopropyl fluorophosphate), but not inactivated by surface active reagents such as DBS (sodium dodecylbenzene sulfonate) and SLS (sodium lauryl sulfate). Moreover, EDTA (ethylendiaminetetra acetic acid) and PCMB ( $p$-chloromercuribenzoate) showed no inhibitory effect on the enzyme (Table III).

\section{Amino acid composition and $N$-terminal}

The amino acid analysis was carried out with the samples hydrolyzed with constant 
boiling $\mathrm{HCl}$ for 24,48 and $72 \mathrm{hr}$ at $110^{\circ} \mathrm{C}$. The values for threonine and serine were those obtained by extraporating to zero time of hydrolysis. Tryptophane content was calcu-

\section{TABLE III. EFFECT OF VARIOUS INHIBITORS ON ENZYME ACTION}

The enzyme was incubated with the reagent in $0.02 \mathrm{M}$ Tris- $\mathrm{HCl}$ buffer $\left(\mathrm{pH} 7.0\right.$ ) at $25^{\circ} \mathrm{C}$ for $30 \mathrm{~min}$ and residual activity was measured.

\begin{tabular}{lcc}
\hline Inhibitor & Concentration & Relative activity \\
\hline None & - & $100 \%$ \\
DBS & $0.2 \%$ & 100 \\
SLS & $0.2 \%$ & 100 \\
EDTA & $5 \times 10^{-3} \mathrm{M}$ & 103 \\
PCMB & $10^{-3} \mathrm{M}$ & 110 \\
DFP & $10^{-3} \mathrm{M}$ & 1 \\
Urea & $6 \mathrm{M}$ & 1 \\
\hline
\end{tabular}

Table IV. Amino Acid Compositions of Alkaline Proteases

\begin{tabular}{lrrrr}
\hline \multicolumn{1}{c}{ Amino acid } & No. 221 & $\begin{array}{l}\text { B. sub- } \\
\text { tilis }\end{array}$ & BPN121 & $\begin{array}{c}\text { B. sub. } \\
\text { Carlsberg }\end{array}$ \\
\hline Tryptophane & 5 & 3 & 3 & 1 \\
Lysine & 6 & 6 & 11 & 9 \\
Histidine & 8 & 5 & 6 & 5 \\
Arginine & 8 & 3 & 2 & 4 \\
Aspartic acid & 29 & 20 & 28 & 28 \\
Threonine & 18 & 14 & 13 & 19 \\
Serine & 23 & 37 & 37 & 32 \\
Glutamic acid & 16 & 12 & 15 & 12 \\
Proline & 16 & 10 & 14 & 9 \\
Glycine & 39 & 25 & 33 & 35 \\
Alanine & 45 & 27 & 37 & 41 \\
Valine & 27 & 20 & 30 & 31 \\
Methionine & 4 & 3 & 5 & 5 \\
Isoleucine & 9 & 12 & 13 & 10 \\
Leucine & 22 & 12 & 15 & 16 \\
Tyrosine & 7 & 9 & 10 & 13 \\
Phenylalanine & 2 & 2 & 3 & 4 \\
Half cystine & 0 & 0 & 0 & 0 \\
\hline
\end{tabular}

11) D. Tsuru, H. Kira, T. Yamamoto and J. Fukumoto, J. Agr. Biol. Chem., 31, 330 (1967).

12) F. S. Markalnd and E. L. Smith, J. Biol. Chem., 242, 5198 (1967).

13) E. L. Smith, R. J. Delange, W. H. Evans, M. London and F.S. Markland, J. Biol. Chem., 243, 2184 (1968).
Table V. Physical and Chemical Properties of Alkaline Proteases

\begin{tabular}{lccc}
\hline & No. 221 & $\begin{array}{c}\text { B. sub- } \\
\text { tilisil }\end{array}$ & BNP'141 \\
\hline$E_{\text {lcm }}^{1 \%}$ at $280 \mathrm{~m} \mu$ & 12.5 & 11.9 & 11.7 \\
$S_{20}$ & 3.5 & 2.89 & 2.77 \\
Molecular weight & 30,000 & 22,700 & 27,700 \\
Isoelectric point & $<9.4$ & $7.5 \sim 8$ & 7.8 \\
Optimum pH & 11.5 & 10.5 & 10.5 \\
Specific activity & \multicolumn{3}{c}{} \\
unit/mg protein & 18,000 & 2,300 & 2,200 \\
N-Terminal & alanine & alanine & alanine \\
$\mathrm{C}, \%$ & 48.04 & 50.86 & 49.50 \\
$\mathrm{H}, \%$ & 6.62 & 7.18 & 7.5 \\
$\mathrm{~N}, \%$ & 16.07 & 15.9 & 16.88 \\
$\mathrm{~S}, \%$ & 0.82 & 0.44 & 0.76 \\
\hline
\end{tabular}

lated from the ultraviolet absorption of the enzyme dissolved in $0.1 \mathrm{~N} \mathrm{NaOH}$ solution. Analysis of the oxidized preparation by performic acid showed that the enzyme did not contain cystine. Table IV shows amino acid composition of the alkaline protease. $\mathrm{N}$ Terminal analysis showed that N-terminal of the enzyme was alanine. No other DNP-amino acid was detected. For the confirmation of DNP-alanine, hydrolysis by ammonium hydroxide was applied to the DNP-amino acid fraction and the regenerated amino acid was also identified as alanine by an amino acid analyzer. Table $\mathrm{V}$ summaries physical and chemical properties of the enzyme.

\section{DISCUSSION}

The strain of Bacillus No. 221 isolated from soil produces large amount of new alkaline protease in alkaline media. This strain can grow slowly in neutral media, but no alkaline protease was detected. Taxonomic position of this strain will be reported elsewhere together with other Bacilli which grow preferentially or obligatorily in alkaline media. In this series of work, I would like to call these

14) H. Matsubara, C. B. Kasper, D. M. Brown and E. L. Smith, J. Biol. Chem., 240, 1125 (1965). 
microorganisms "alkalophilic microorganisms."

The alkaline protease of Bacillus No. 221 was purified by passing through a DEAE-cellulose column followed by CM-cellulose column chromatography. The crystalline enzyme is a homogenous protein under the tested conditions: ultracentrifugal analysis, Tiselius electrophoresis, cellulose acetate electrophoresis, and gel filtration. The enzyme has optimum $\mathrm{pH}$ at 11.5 toward casein. This value is higher than those of alkaline proteases of Bacillus subtilis, which are about $\mathrm{pH} 10 \sim 10.5$. The No. 221 protease was completely inactivated by DFP, therefore this enzyme can be classified as a serine enzyme. The $B$. subtilis alkaline proteases are also inactivated by DFP. It is noteworthy that the specific activity toward casein was about 18,000 units/mg. Under the same assay method, $\alpha$-chymotrypsin was 2,500 and trypsin 1,700 units/mg. Specific activities of alkaline proteases of $B$. subtilis were 2,000 3,000 units/mg. Molecular weight of the enzyme estimated by Archibald method was approximately $3 \times 10^{4}$ and the gel filtration method gave $1.5 \times 10^{4}$ The gel filtration method may not be applied to the No. 221 enzyme due to the high isoelectric point. For example, lysozyme $(I p=11)$ deviated from the standard curve of proteins and gel filtration method gave molecular weight of 8,000 .

As the results, I wish to conclude that the No. 221 protease is entirely different from known alkaline proteases of $B$. subtilis such as BPN' etc. in their properties except $\mathrm{N}$ terminal of the enzyme protein.

Acknowledgement. I thank Dr. Y. Ikeda for his suggestion and critical reading of the manuscript. Thanks are also due to $\mathrm{Mr}$. M. Chijimatsu of the Institute for his courtesy on ultracentrifugal and amino acid analyses. 